\title{
Luteinizing hormone response to an oestradiol challenge in 5 intersex pigs possessing ovotestes*
}

\author{
C. Chalmers, B. Cook $\uparrow$, G. R. Foxcroft $\ddagger \S$ and R. H. F. Hunter \\ School of Agriculture, University of Edinburgh, Edinburgh EH9 3JG, UK; \\ †University Department of Pathological Biochemistry, Royal Infirmary, Glasgow G4 OSF, UK; and \\ $\$ P E S$, Animal Physiology, University of Nottingham, Faculty of Agricultural Science, \\ Sutton Bonington, Loughborough, Leics LE12 5RD, UK
}

\begin{abstract}
Summary. After challenge with oestradiol benzoate, the mean maximum LH concentration in $5 \mathrm{XX}$ intersex pigs possessing ovarian and testicular tissue, or only testicular tissue, was $2.10( \pm 0.41) \mathrm{ng} / \mathrm{ml}$ compared with $8.9 \mathrm{ng} / \mathrm{ml}$ in mature domestic gilts. These results indicate that exposure of the pig brain to testosterone before Day 30 of gestation is important, or that early testicular secretions other than testosterone are involved in the determination of brain gender. The observation that some intersex pigs show normal oestrous cycles implies that the response to these prenatal factors is primarily quantitative rather than qualitative.
\end{abstract}

Keywords: LH; oestradiol; intersex; ovotestes; pigs

\section{Introduction}

The stimulatory (i.e. positive) oestrogen feedback mechanism that causes a surge of luteinizing hormone $(\mathrm{LH})$ release, and hence ovulation in mature female mammals, has been shown to be absent in the male of several species, including the rat (Neill, 1972), hamster (Buhl et al., 1978), sheep (Bolt, 1971; Karsch \& Foster, 1975) and pig (Ford \& Schanbacher, 1977). In rhesus monkeys, by contrast, administration of oestradiol benzoate to males and females can elicit an $\mathrm{LH}$ surge (Karsch et al., 1973). Although sexually dimorphic responses to oestradiol are evident in miniature pigs at 14 days of age (Elsaesser et al., 1978b), Foxcroft et al. (1984) suggested an ovarian-, possibly oestrogen-, dependent maturation of the feedback mechanism in domestic gilts. When oestrogen challenges were made at 160 days, gilts ovariectomized at 60 days of age showed a smaller LH peak and a greater interval between oestradiol administration and the gonadotrophin surge than did gilts ovariectomized at 130 days or ovariectomized at 60 days and treated with oestradiol to Day 130. Prenatal exposure of domestic pigs to testosterone (via the mother) significantly impairs the LH response to oestradiol benzoate in adult females (Elsaesser \& Parvizi, 1979), as does prenatal exposure to androgens in mice (Barraclough, 1955) and sheep (Clarke \& Scaramuzzi, 1978), implying that sexual differentiation of the oestradiol feedback mechanism occurs prenatally. In contrast, neonatal exposure of female rats to appropriate doses of androgen abolishes the positive feedback effect of oestradiol.

Intersex pigs occur at an estimated frequency of $0.1 \%$ to $1 \%$ in commercial pig herds (Bäckström \& Henricson, 1971; Hunter et al., 1982). Most of the animals are genetically XX

\footnotetext{
* Reprint requests to Dr B. Cook.

$\$$ Present address: Department of Animal Science, Faculty of Agriculture and Forestry, University of Alberta, Edmonton, Alberta, Canada T6G 2P5.

-Present address: Centre for Research in Animal Reproduction, Faculty of Veterinary Medicine, University of Montreal, CP 5000, St Hyacinthe, Quebec, Canada J2S 7C6.
} 
(Breeuwsma, 1970; Miyake, 1973) but are identified due to partial masculinization of the genitalia caused by the steroid and protein hormone secretions of various amounts of testicular tissue. Although many intersex pigs are sterile, pregnancies have been recorded (Scofield et al., 1969; Hunter et al., 1985), providing evidence of a mature feedback response of gonadotrophins to oestradiol, despite the presumed exposure of the brain to prenatal testicular androgens.

A study of 5 intersex animals revealed different degrees of boar-like behaviour, but no detectable oestrous cycles, indicating masculinization of the brain. The present experiment was therefore designed to determine the brain gender of these pigs as defined by their $\mathrm{LH}$ responses to an oestradiol challenge.

\section{Materials and Methods}

\section{Animals}

The animals were all Landrace $\times$ Large White/Landrace pigs weighing between 90 and $150 \mathrm{~kg}$ at the time of the experiment. They had been identified as intersex animals at 2-3 months of age by examination of the vulva and clitoris. Karyotypes were XX as determined from blood leucocyte culture following the techniques of Lin et al. (1976) and Buckland et al. (1976). In the absence of detectable oestrous cycles, mid-ventral laparotomies were performed. Anaesthesia was induced with pentobarbitone sodium and maintained, after intubation, by a mixture of halothane, nitrous oxide and oxygen. The reproductive tract and gonads were exteriorized, when possible, and inspected for signs of previous cyclic activity. Tracts were recovered at slaughter for more detailed examination.

Animals received intramuscular injections $(60 \mu \mathrm{g} / \mathrm{kg}$ body weight) of oestradiol benzoate in ethyl oleate (Intervet Laboratories Ltd, Cambridge, UK) and were observed for signs of oestrus, vulval reddening and swelling being taken as an indication of an oestrogenic response.

\section{Blood sampling}

Indwelling jugular cannulae were fitted to permit frequent bleeding. Samples were collected into heparinized tubes, centrifuged at $1500 \mathrm{~g}$ for $10 \mathrm{~min}$ at $4^{\circ} \mathrm{C}$, and plasma stored at $-20^{\circ} \mathrm{C}$ until assay. For $\mathrm{LH}$ analysis, samples $(4 \mathrm{ml})$ were taken every $24 \mathrm{~h}$ for $48 \mathrm{~h}$ before, and every $4 \mathrm{~h}$ for up to $112 \mathrm{~h}$ after, the oestradiol injection. Samples of $10 \mathrm{ml}$ were collected every $12 \mathrm{~h}$ for oestradiol analysis, except for 6-h samples taken immediately after the challenge. Daily samples were also assayed for progesterone and testosterone.

\section{Assays}

$L H$ radioimmunoassay. Plasma $L H$ concentrations were determined by an homologous double-antibody $R I A$. The primary antiserum was raised in a goat immunized against a purified pig LH preparation. SDG-2-65 (0.96$1.18 \times$ NIH-oLH-S19, by bioassay). The first booster injection, 6 months after initial immunization using Freund's complete adjuvant, produced a series of sera with good titres and specificity. The antiserum characterized in the present assays, GRF-G $81 / 1$, bound approximately $20 \%$ of radiolabelled pig LH in the absence of unlabelled antigen, at an initial dilution of 1:60 000. Other assay methodology was as described previously (Foxcroft et al., 1984) with the following minor modification. To enhance precipitation of antibody-bound hormone, a second antibody (donkey anti-goat gamma globulin, raised at Sutton Bonington) at 1:40 dilution was preincubated for $24 \mathrm{~h}$ with $10 \%(\mathrm{w} / \mathrm{v})$ polyethylene glycol 6000 (PEG; BDH Ltd, Poole, UK); $200 \mu \mathrm{l}$ of the PEG anti-goat gamma-globulin were then added to assay tubes and a minimum period of $8 \mathrm{~h}$ incubation at $4^{\circ} \mathrm{C}$ then followed before centrifugation and aspiration. Reproducible standard curves were obtained with this assay with a range of standard potencies from 0.01 to $0.5 \mathrm{ng}$ / tube and the overall sensitivity, defined as $90 \%$ of total binding, was $0.02 \mathrm{ng} /$ tube. A standard plasma pool, routinely assayed at 50,100 and $200 \mu \mathrm{l}$ showed parallelism to the standard curve. The recovery of pig LH when added to pig plasma of known potency ranged from 92 to $102 \%$, confirming accuracy. The specificity of the antibody was checked by carrying out cross-reaction studies with pig prolactin and pig FSH; at $50 \%$ binding these hormones showed 0.17 and $0.88 \%$ cross-reactivity, respectively. All samples were run at $100 \mu \mathrm{l}$ in duplicate in a single assay for which the intra-assay coefficient of variation was $<10 \%$.

Steroid assays. Radioimmunoassays for oestradiol, progesterone and testosterone were as described by Cook et al. (1977), except that bound and free steroids were separated using a second antibody (Scottish Antibody Production Unit, Law Hospital, Carluke, Lanarkshire, UK). Oestradiol antiserum was obtained from Immunodiagnostics Ltd, Usworth Hall, Washington, Tyne and Wear, UK. Cross-reactions were $8.7 \%$ with oestrone for the oestradiol antiserum, $4.3 \%$ and $1.8 \%$ with deoxycorticosterone and corticosterone respectively for the progesterone antiserum and $33.8 \%$ and $6.4 \%$ with DHT and androstenedione respectively for the testosterone antiserum. Other cross-reactions were $<1 \%$ (Cook et al., 1977). The assay sensitivities were oestradiol $59 \mathrm{pmol} / 1$, progesterone $2.2 \mathrm{nmol} / 1$ and testosterone $\mathrm{l} \cdot 0 \mathrm{nmol} / \mathrm{l}$. 


\section{Results}

Table 1 summarizes the observations on the behaviour and morphology of the intersex pigs. Figure 1 shows the $\mathrm{LH}$ and oestradiol profiles before and after oestradiol benzoate injections. The maximum LH concentration after injection was $2 \cdot 10( \pm 0.41) \mathrm{ng} / \mathrm{ml}$ (mean \pm s.e.) at $86( \pm 6 \cdot 8) \mathrm{h}$. In Pigs I 2 and I4, higher concentrations were recorded before the oestradiol benzoate injection, than after. In all animals, plasma oestradiol rose after the oestradiol challenge. The mean concentration $84 \mathrm{~h}$ after the injection was $402( \pm 115) \mathrm{pmol} / \mathrm{l}$. Following the challenge, progesterone concentrations remained below $10 \mathrm{nmol} / 1$ in 4 animals, but in Pig 193, progesterone concentrations were between 40 and $75 \mathrm{nmol} / 1$. Testosterone concentrations were, in all animals, $<3.0 \mathrm{nmol} / 1$ throughout sampling.

Table 1. Summary of observations on 5 intersex pigs

\begin{tabular}{lllll}
\hline Pig & Behaviour & External morphology & Morphology of tract & Morphology of gonads \\
\hline 12 & Not assessed & $\begin{array}{l}\text { Upturned vulva, hyper- } \\
\text { trophied clitoris }\end{array}$ & $\begin{array}{l}\text { Fluid-filled uterus of } \\
\text { normal morphology; }\end{array}$ & Testis on right and left \\
& & $\begin{array}{l}\text { Wolffian duct develop- } \\
\text { ment expressed as } \\
\text { epididymis }\end{array}$ & &
\end{tabular}

14 Aggressive with boar; no interest in oestrous gilt despite inducing 'standing response'

15

Not aggressive with boar; no detectable response to oestrous gilt

17 Aggressive with boar; excessive salivation; mounted oestrous gilt

193 Not assessed
Upturned vulva; hypertrophied clitoris; prominent tusks; mid-ventral penile sheath

Upturned vulva; hypertrophied clitoris; fatfilled scrotal sacs

Upturned vulva; hypertrophied clitoris; prominent tusks

Upturned vulva; hypertrophied clitoris
Fluid-filled tract; epididymis associated with right gonad

\section{Immature dimensions} but normal morphology

Normal uterus; ampullary portion of oviducts rudimentary; pampiniform plexus associated with each gonad

Normal uterus; Wolffian duct development on right; normal oviduct on left
Testis on right; ovotestis (90\% testicular) on left

Not located on right; underdeveloped (could not be identified as ovarian or testicular) on left

Ovotestis (70\% testicular; $>4$ follicles $8-$ $10 \mathrm{~mm}$; no corpora lutea) on right; ovotestis ( $90 \%$ ovarian; $>12$ cystic follicles; no corpora lutea) on left

Testis on right; ovary (16 cystic follicles) on left

\section{Discussion}

By 160 days of age, domestic gilts are able to respond to an oestradiol benzoate challenge with a surge release of LH 37-55 h later (Elsaesser \& Foxcroft, 1978; Foxcroft et al., 1984), the average surge concentration being $8.9 \mathrm{ng} / \mathrm{ml}$. None of the intersex animals in the present study showed an LH surge comparable to this despite raised oestradiol concentrations. The mean pretreatment $\mathrm{LH}$ concentration in the present study was $1.62 \mathrm{ng} / \mathrm{ml}$ and the mean post-treatment concentration was $2 \cdot 10 \mathrm{ng} / \mathrm{ml}$. In all animals, after the oestradiol benzoate challenge, peripheral oestradiol remained within the range of peak preovulatory concentrations reported for cyclic gilts (Henricks et al., 1972; Van de Wiel et al., 1981).

Pig I5 showed an $\mathrm{LH}$ rise above pretreatment levels, reaching a maximum $96 \mathrm{~h}$ after the oestradiol dose. Such a response indicates the operation of an immature feedback mechanism similar to 

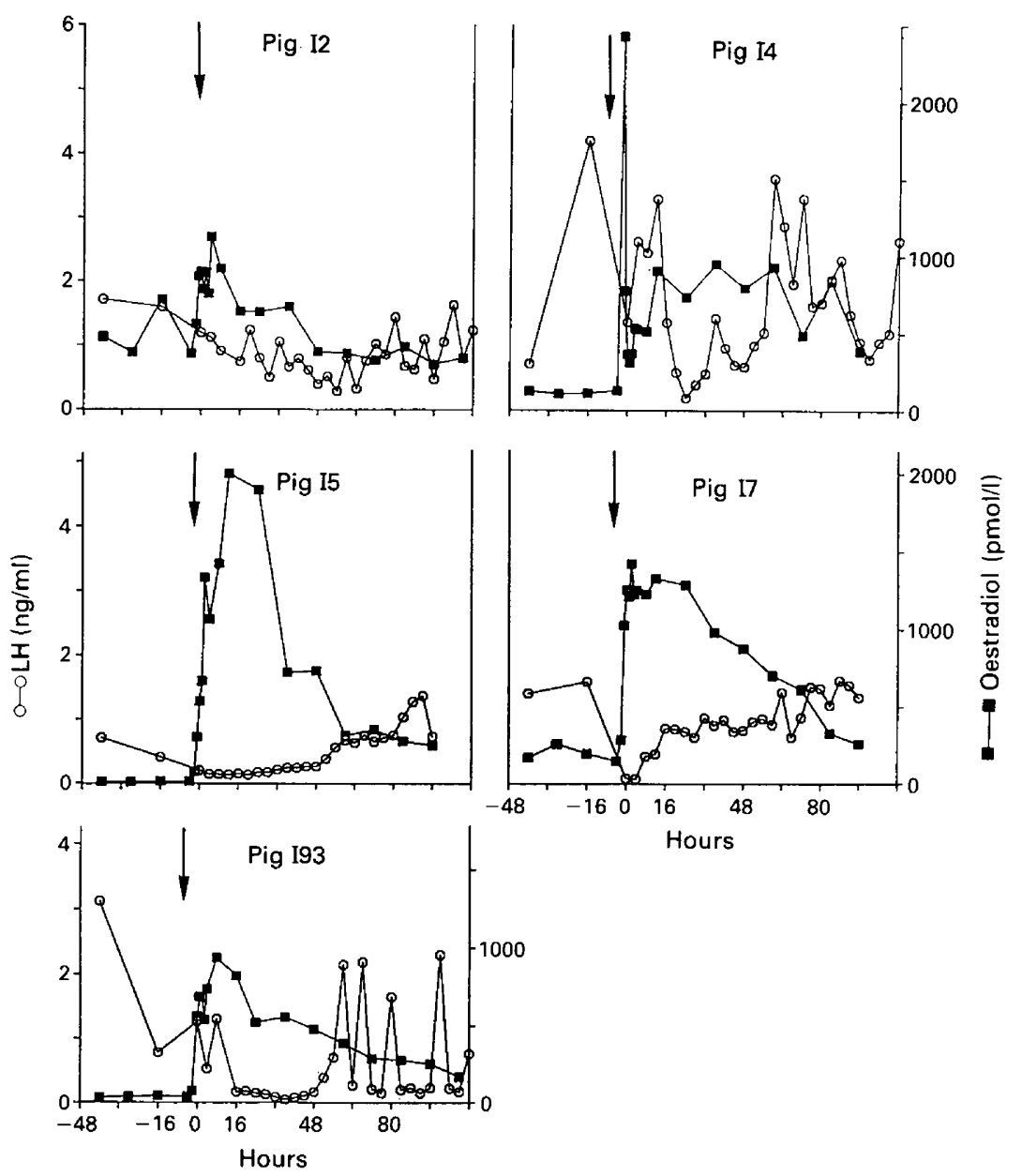

Fig. 1. Plasma concentrations of $\mathrm{LH}$ and oestradiol in 5 intersex pigs before and after an injection of oestradiol benzoate given at time 0 (arrow). (For comparison, oestrogen injection gave a peak concentration of $8.9 \mathrm{ng} \mathrm{LH} / \mathrm{ml}$ at $37 \mathrm{~h}$ in normal gilts (Foxcroft et al., 1984), whereas in normal males a maximum of $1.7 \mathrm{ng} / \mathrm{ml}$ was reached at $90 \mathrm{~h}$ (Ford \& Schanbacher, 1977).)

that seen in 60-day-old domestic gilts (Foxcroft et al., 1984), a mechanism which the authors suggest matures due to exposure to ovarian follicular secretions, possibly oestrogens. The low preinjection concentrations of oestradiol in Pig I5 support this view, but the masculinized external genitalia indicate prenatal exposure to testosterone, which may also be responsible for the diminished $\mathrm{LH}$ release.

In 4 animals, progesterone concentrations were within the range corresponding to follicularphase concentrations in cyclic gilts (Stabenfeldt et al., 1969; Edqvist \& Lamm, 1971). In Pig 193, however, a high progesterone concentration (presumably secreted by luteal tissue discovered during histological examination) may have prevented an LH surge after the oestradiol injection; oestradiol given during the luteal phase of the oestrous cycle will not elicit an LH surge in rats (Tapper et al., 1974), sheep (Karsch et al., 1978) or women (Leyendecker et al., 1972). In all 5 
intersexes, the pattern of the LH release was closer to that seen in castrated adult male pigs (Ford \& Schanbacher, 1977) than to normal females (Elsaesser \& Foxcroft, 1978; Foxcroft et al., 1984) despite the XX karyotypes.

Prenatal exposure of the brain to testosterone is thought to be the cause of sexual differentiation of the feedback response to oestradiol in rats, treatment with testosterone propionate during pregnancy abolishing the LH response in the female offspring (Neill, 1977). In rhesus monkeys, however, prenatal testosterone did not affect adult LH secretion; both sexes responded to an oestradiol injection with a surge release of LH (Steiner et al., 1976). In the sheep, the effect of prenatal testosterone treatment on the female may be quantitative rather than qualitative, since the LH response to oestradiol in the adult is reduced but not abolished (Clarke \& Scaramuzzi, 1978). This may also be the case in pigs (Elsaesser \& Parvizi, 1979).

Fetuses treated with testosterone injection into the dam between Days 30 and 70 of gestation are more likely to show a masculinized LH response profile as adults than fetuses similarly treated during the second half of gestation (Elsaesser \& Parvizi, 1979). Maximum testosterone content of the fetal pig testis is reached between Days 35 and 38 ( $>4 \mathrm{ng} /$ pair) (Raeside \& Sigman, 1975) and in umbilical arterial serum on Day $35(>4 \mathrm{ng} / \mathrm{ml})$, concentrations in the female fetus being undetectable at this stage (Ford et al., 1980). These changes in testosterone concentration follow the morphological development of Leydig cells within the testes (Moon \& Hardy, 1973; Pelliniemi, 1975). It is therefore assumed that differentiation of the brain in the pig is due to exposure to testosterone around Day 35 of pregnancy (Ford et al., 1980). However, exposure of the 30-day-old fetus to testosterone, either via the pregnant sow (Elsaesser \& Parvizi, 1979) or directly (Elsaesser et al., 1978a), does not completely abolish the LH response to oestradiol, or ovulation, in the adult. The presence of testicular tissue in the intersex pigs of this study apparently masculinizes the brain, despite testosterone concentrations being below those reported for mature intact (miniature) or castrated (domestic) pigs (Ellendorff et al., 1975; Ford \& Schanbacher, 1977). This indicates (1) that the brain exposure to testosterone before Day 30 of gestation is important, or (2) that testosterone is not the sole determinant of brain gender. Since development of a normal male reproductive tract involves regression of the Müllerian hormone (Jost, 1947), this hormone could also be implicated in brain defeminization.

Foxcroft et al. (1984) have suggested that the lack of an LH surge mechanism in the male pig is due, not to the presence of neonatal androgen secretion, but to the absence of an ovary during prepubertal life. Although the presence of a sexually dimorphic LH response to oestradiol in newborn pigs (Elsaesser et al., 1978b) would seem to refute this, prenatal ovarian influences may be important in counteracting the defeminizing/masculinizing effects of testicular secretions. Such influences may result in the development of a mature feedback response and ovulation in some intersex pigs (Hunter et al., 1982, 1985). In the intersex pigs used in the present study, testicular secretions were presumably sufficient to cause substantial masculinization of the feedback mechanism.

The mechanism involved in masculinization is not clear. It is known that oestrogen is as effective as testosterone in masculinizing neonatal rat brains, aromatization of testosterone to oestradiol in the brain playing a crucial role (MacLusky \& Naftolin, 1981). An LHRH challenge in male pigs (Pomerantz et al., 1974), and in the intersexes of the present study (results not shown), invokes an LH response, implying that pituitary insensitivity is not a problem. The lack of hypothalamic/pituitary steroid receptors has been suggested (Elsaesser \& Parvizi, 1979) with reference to the rat, in which the stimulatory oestrogen feedback mechanism does not operate until 22 days of age (Caligaris et al., 1972) when maturation of hypothalamic receptors occurs (Plapinger \& McEwen, 1973). Oestrogen receptors may be deficient in the intersex pigs in that no oestrous behaviour was observed after the oestradiol benzoate injection, but inhibition of LH secretion was evident in all animals, indicating at least some hypothalamic/pituitary sensitivity to the steroid, albeit as a negative feedback effect. Oestrogen insensitivity is one explanation for infertility in intersex pigs, although the failure of attempts to induce, with PMSG, ovulation from an ovotestis 
in an anoestrous intersex (Hunter et al., 1985) suggests that these gonads may be unresponsive to gonadotrophins.

We thank Mr F. de Rensis for collaboration in carrying out the LH assays; Mr R. Nichol and Mrs A. Kelly for expert technical assistance; Dr D. F. M. Van de Wiel, Dr J. H. F. Erkens and Dr S. G. Glenn for gifts of pig LH antigen; and the AFRC for a grant.

\section{References}

Bäckström, L. \& Henricson, B. (1971) Intersexuality in the pig. Acta vet. scand. 12, 257-273.

Barraclough, C.A. (1955) Influence of age on the response of preweaning female mice to testosterone propionate. Am. J. Anat. 97, 493-521.

Bolt, D.J. (1971) Changes in the concentration of luteinizing hormone in plasma of rams following administration of oestradiol, progesterone or testosterone. $J$. Reprod. Fert. 24, 435 438.

Breeuwsma, A.J. (1970) Studies of intersexuality in pigs. Doctoral thesis, Drukkerij Bronder-Offset N.V., Rotterdam.

Buckland, R.A., Fletcher, J.M. \& Chandley, A.C. (1976) Characterisation of the domestic horse (Equus caballus) karyotype using G- and C-banding techniques. Experientia 32, 1146-1149.

Buhl, A.E., Normal, R.L. \& Resko, J.A. (1978) Sex differences in estrogen-induced gonadotrophin release in hamsters. Biol. Reprod. 18, 592-597.

Caligaris, L., Astrada, J.J. \& Taleisnik, S. (1972) Influence of age on the release of luteinizing hormone induced by oestrogen and progesterone in immature rats. J. Endocr. 55, 97-103.

Clarke, I.J. \& Scaramuzzi, R.J. (1978) Sexual behaviour and $\mathrm{LH}$ secretion in spayed androgenized ewes after a single injection of testosterone or oestradiol-17 $\beta . J$. Reprod. Fert. 52, 313-320.

Cook, B., Hunter, R.H.F. \& Kelly, A.S.L. (1977) Steroidbinding proteins in follicular fluid and peripheral plasma from pigs, cows and sheep. J. Reprod. Fert. 51, 65-71.

Edqvist, L.E. \& Lamm, A.M. (1971) Progesterone levels in plasma during oestrous cycle of the sow measured by a rapid competitive protein binding technique. $J$. Reprod. Fert. 23, 447-449.

Ellendorff, F., Parvizi, N., Pomerantz, D.K., Hartjen, A., Konig, A., Smidt, D. \& Elsaesser, F. (1975) Plasma luteinizing hormone and testosterone in the adult male pig: 24 hour fluctuations and the effect of copulation. J. Endocr. 67, 403-410.

Elsaesser, F. \& Foxcroft, G.R. (1978) Maturational changes in the characteristics of oestrogen-induced surges of luteinizing hormone in immature domestic gilts. J. Endocr. 78, 455-456.

Elsaesser, F. \& Parvizi, N. (1979) Estrogen feedback in the pig: sexual differentiation and the effect of prenatal testosterone treatment. Biol. Reprod. 20, 1187-1193.

Elsaesser, F., Parvizi, N. \& Ellendorfi, F. (1978a) Effect of prenatal testosterone on the stimulatory estrogen feedback on LH release in the pig. In Hormones and Brain Development, pp. 61-67. Eds G. Dorner \& M. Kawakami. Elsevier/North-Holland Biomedical Press, Amsterdam.
Elsaesser, F., Parvizi, N. \& Ellendorf, F. (1978b) Steroid feedback on luteinizing hormone secretion during sexual maturation in the pig. J. Endocr. 78, 329-342.

Ford, J.J. \& Schanbacher, B.D. (1977) Luteinizing hormone secretion and female behaviour in male pigs. Endocrinology 100, 1033-1038.

Ford, J.J., Christenson, R.K. \& Maurer, R.R. (1980) Serum testosterone concentrations in embryonic and fetal pigs during sexual differentiation. Biol. Reprod. 23, 583-587.

Foxcroft, G.R., Elsaesser, F., Stickney, K., Haynes, N.B. \& Back, H.L. (1984) Ovarian oestrogen-dependent maturation of the LH/FSH surge mechanism during prepubertal development in the gilt. J. Endocr. 101, $371-380$.

Henricks, D.M., Guthrie, H.D. \& Handlin, D.L. (1972) Plasma estrogen, progesterone and luteinizing hormone levels during the oestrous cycle in pigs. Biol. Reprod. 6, 210-218.

Hunter, R.H.F., Baker, T.G. \& Cook, B. (1982) Morphology, histology and steroid hormones of the gonads in intersex pigs. J. Reprod. Fert. 64, 217-222.

Hunter, R.H.F., Cook, B. \& Baker, T.G. (1985) Intersexuality in five pigs, with particular reference to oestrous cycles, the ovotestis, steroid hormone secretion and potential fertility. J. Endocr. 106, 233-242.

Jost, A. (1947) Recherches sur la differentiation sexuelle de l'embryon de lapin. Archs Anat. microsc. Morph. exp. 36, 271-315.

Karsch, F.J. \& Foster, D.L. (1975) Sexual differentiation of the mechanism controlling the preovulatory discharge of luteinizing hormone in sheep. Endocrinology 97, 373-379.

Karsch, F.J., Dierschke, D.J. \& Knobil, E. (1973) Sexual differentiation of pituitary function: apparent difference between primates and rodents. Science, $N Y 179$, $484-486$.

Karsch, F.J., Legan, S.J., Ryan, K.D. \& Foster, D.L. (1978) The feedback effects of ovarian steroids on gonadotrophin secretion. In Control of Ovulation, Ch. 3, pp. 29-48. Eds D. B. Crighton, N. B. Haynes, G. R. Foxcroft \& G. E. Lamming. Butterworth, London.

Leyendecker, G., Wardlaw, S. \& Nocke, W. (1972) Experimental studies on the endocrine regulations during the periovulatory phase of the human menstrual cycle. Acta endocr., Copenh. 71, 160-178.

Lin, C.C., Newton, D.R., Smink, W.K. \& Church, R.B. (1976) A rapid and simple method for the isolation and culture of leukocytes for chromosome analysis in domestic animals. Can. J. Anim. Sci. 56, 27-31. 
MacLusky, N.J. \& Naftolin, F. (1981) Sexual differentiation of the central nervous system. Science, $N Y$ 211, 1294-1303.

Miyake, Y-I. (1973) Cytogenetical studies on swine intersexes. Jap. J. vet. Res. 21, 41-49.

Moon, Y.S. \& Hardy, M.H. (1973) The early differentiation of the testis and interstitial cells in the fetal pig, and its duplication in organ culture. Am.J. Anat. 138, 253-268.

Neill, J.D. (1972) Sexual differences in the hypothalamic regulation of prolactin secretion. Endocrinology $\mathbf{9 0}$, $1154-1159$.

Pelliniemi, L.J. (1975) Ultrastructure of the early ovary and testis in pig embryos. Am. J. Anat. 144, 89-122.

Plapinger, L. \& McEwan, B.S. (1973) Ontogeny of estradiol-binding sites in rat brain. I. Appearance of presumptive adult receptors in cytosol and nuclei. Endocrinology 93, 1119-1128.

Pomerantz, D.K., Ellendorfi, F., Elsaesser, F., Konig, A. \& Smidt, D. (1974) Plasma LH changes in intact adult, castrated adult and pubertal male pigs following various doses of synthetic luteinizing hormonereleasing hormone (LH-RH). Endocrinology 94, 330-335.
Raeside, J.I. \& Sigman, D.M. (1975) Testosterone levels in early fetal testes of domestic pigs. Biol. Reprod. 13, 318-321.

Scofield, A.M., Cooper, K.J. \& Lamming, G.E. (1969) The distribution of embryos in intersex pigs. $J$. Reprod. Fert. 20, 161-163.

Stabenfeldt, G.H., Akins, E.L., Ewing, L.L. \& Morrissette, M.C. (1969) Peripheral plasma progesterone levels in pigs during the oestrous cycle. J. Reprod. Fert. 20, 443-449.

Steiner, R.A., Clifton, D.K., Spies, H.G. \& Resko, J.A. (1976) Sexual differentiation and feedback control of luteinizing hormone secretion in the Rhesus monkey. Biol. Reprod. 15, 206-212.

Tapper, C.M., Greig, F. \& Brown-Grant, K. (1974) Effects of steroid hormones on gonadotrophin secretion in female rats after ovariectomy during the oestrous cycle. J. Endocr. 62, 511-525.

Van de Wiel, D.F.M., Erkens, J., Koops, W., Vos, E. \& Van Landeghem, A.A.J. (1981) Periestrous and Midluteal time courses of circulating LH, FSH, prolactin, estradiol-17 $\beta$ and progesterone in the domestic pig. Biol. Reprod. 24, 223-233.

Received 29 December 1988 